Food, Dairy and Home Economic Research

http:/www.journals.zu.edu.eg/journalDisplay.aspx?Journalld=1\&queryType=Master

\title{
STUDY THE LEVEL OF NUTRITIONAL KNOWLEDGE OF MOTHERS OF BREAST AND ARTIFICIAL FEEDING IN SHARKIA GOVERNORATE
}

\author{
Esraa S.T. Hassan ${ }^{* 1}$, M.M.Z. El-Abbassy ${ }^{1}$, Manal M.E.M. Shehata ${ }^{2}$ and Azza S. Abdel-Ghany ${ }^{2}$ \\ 1. Food Sci. Dept., Fac. Agric., Zagazig Univ., Egypt \\ 2. Food Sci. Dept. (Rural Home Econ.), Fac. Agric., Zagazig Univ., Egypt
}

Received: 03/09/2019; Accepted: 15/09/2019

\begin{abstract}
The aim of this work was to study the level of nutritional knowledge of mothers about breast and artificial feeding, sources of nutritional knowledge of mothers was also studied. This cross-sectional study was conducted on 200 mothers, selected randomly from urban and rural areas in Sharkia Governorate, Egypt during the period from March to May, 2019. All mothers filled a questionnaire to evaluate their knowledge about breast and artificial feeding. The results showed that the highest percentage of working and housewives mothers (50.0 and 53.1\%) were aged 25-32 years old, respectively. About 65.8 and $46.3 \%$ of the working mother and housewives mothers were from urban area, respectively. The majority of working mothers were educated. The results revealed that the majority of working and housewives mothers $(97.5$ and $92.1 \%)$ were married. The results indicated that the children sex was $63.2 \%$ male and $36.8 \%$ female for working mothers. Whereas, they were $46.9 \%$ male and $53.1 \%$ female for housewives. It is obvious that the $57.9 \%$ of working mothers had children their age were (576-850) days. Whereas, the highest proportion of housewives $(37.7 \%)$ had children their age was 25-300 days. The results indicated that the percentage of good nutrition children was 97.5 and $89.5 \%$ of housewives and working mothers, respectively. The results declared that the working and housewives mothers get nutritional knowledge by percent 63.2 and $46.3 \%$ from visiting doctor, respectively. The results illustrated that the highest percentage of working and housewives mothers ( 84.2 and $60.5 \%$ ) had low level of general knowledge about breast feeding. Also, most of working and housewives mothers (76.3 and 62.3\%) had low level of general knowledge about artificial feeding. It can be concluded that the most of subjects had low level of knowledge about breast and artificial feeding. Therefore, the recommendions are the use of programs to raise awareness for mothers about breast and artificial feeding.
\end{abstract}

Key words: Nutritional knowledge, breast feeding, artificial feeding, housewives and working mothers.

\section{INTRODUCTION}

Knowledge is a complex scheme of beliefs, information, and skills gained through experience and education. In terms of nutrition and eating, knowledge can be described as the familiarization of the benefits of food and nutrients and its effect on health and the ability to remember and recall specific terminology and information on the subject (Zarnowiecki et al., 2012; Romanos-Nanclares et al., 2018).

Healthy eating behaviors in childhood are very important. It helps prevent malnutrition, growth retardation, and acute child nutrition problems, in addition to preventing chronic, long-term health problems such as cardiovascular diseases, type 2 diabetes, cancer, obesity, and osteoporosis (Yabanc et al., 2013). Parents are mostly responsible on this subject (Nicklas, 1995; Nicklas and Hayes, 2008).

Attitudes are measured to identify individual positive or negative disposition regarding a health problem, dietary practices, nutritional recommendations, dietary guidelines, or dietary preferences. Parents are effective on their children's eating behaviors and preferences,

\footnotetext{
*Corresponding author: Tel. : +201098114851

E-mail address: esobhy55@yahoo.com
} 
especially mothers who are the role models of their children about eating behaviors. Eating behaviors evolve during the first years of life as biological and behavioral processes directed toward meeting requirements for health and growth. Parents powerfully shape children's early experiences with food and eating, providing both genes and environments for children (Mardhiah et al., 2019).

Therefore, it is important to determine mother's eating habits to support healthy nutrition of both child and mother. Public health strategies should focus on encouraging parental healthy-eating attitudes rather than simply educating parents on what to feed their children, recognizing the important influence of parental behavior on children's practices (Romanos-Nanclares et al., 2018). Eating behaviors of the mother are affected by some factors such as socioeconomic status, educational status, age, working position, and knowledge level of nutrition of mother (Variyam et al., 1999; Vereecken and Maes, 2010; McLeod et al., 2011). Also, poor knowledge about nutrition and food diversity of caregivers influence the feeding practices of mothers which can be improved by counseling the caregivers on correct feeding practices by knowledgeable health workers (Manikyamba $\boldsymbol{e t}$ al., 2015). It is assumed that nutritional knowledge level of the mother affects eating behaviors of their children (Berihu et al., 2013). It is clear from the above mentioned the importance of this study which was designed to assess nutritional knowledge of mothers regarding breast and artificial feeding in Sharkia Governorate.

\section{MATERIALS AND METHODS}

The present cross-sectional study was conducted on working and housewife mothers that have a child aged 3 years old in Sharkia Governorate, Egypt. An orally expressed consent was taken by the participating mothers. A total of 200 mothers were interviewed who were randomly selected from urban areas $\left(10^{\mathrm{Th}}\right.$ of RamadanBelbeis- Fakous- El-Huseiniya- Zagazig- Minya El-kamh- Kafr saqr) and rural areas (Manshyet Rghep- Samakin Elgharb- Almonagaa- AboKhalilEliwa-Sooad-Elmalakyin Elbaharya- Elhamadyeen).
A structured questionnaire was prepared for the study during the period from March to May, 2019. The data were obtained through interview with each mother to answer the questions found in designed questionnaire sheet. The questionnaire was comprised of four parts as follow: personal and socio-demographic characteristics of respondents, general knowledge about breast and artificial feeding.

\section{Knowledge about Breast Feeding}

The items were scored as follows, (I know) answer was scored (3), (to some extent) answer was scored (2) and (I don't know) answer was scored (1).

\section{Knowledge About Formula Feeding}

The items were scored as follows, (I know) answer was scored (3), (to some extent) answer was scored (2) and (I don't know) answer was scored (1).

\section{Statistical Analysis}

Statistical Package for Social Sciences (SPSS) version 20 was used to analyze the collected questionnaire date. The data were presented in the form of frequencies, percentages and analytical tests including Chi-square. For all tests, at $\mathrm{P} \leq 0.05$ was considered significant.

\section{RESULTS AND DISCUSSION}

\section{Personal and Socio-Demographic Characteristics of Respondents}

\section{Age of mother}

Table 1 describs the distribution of participants mothers according to their age. It is obvious that the highest percentage of working mothers $(50 \%)$ was aged 25-32 years old, while those aged 1724 was $13.2 \%$, and working mothers aged $33-40$ was $36.8 \%$. The highest proportion of housewives (53.1\%) was aged 25-32, while those aged 17-24 was $38.9 \%$ and those aged $33-40$ was $8.0 \%$. It is evident from these results that there were significant differences in working mothers and housewives according to the age of mother.

\section{Residence area}

Table 2 describs distribution of respondents according to residence area. About 65.8 and $46.3 \%$ 
Table 1. Distribution of mothers participating in the study according to their age

\begin{tabular}{|c|c|c|c|c|c|c|}
\hline \multirow[t]{2}{*}{ Age of mother } & \multicolumn{2}{|c|}{ Working } & \multicolumn{2}{|c|}{ Housewives } & \multicolumn{2}{|c|}{ Total } \\
\hline & No. & $(\%)$ & No. & $(\%)$ & No. & $(\%)$ \\
\hline Low 17-24 & 5 & 13.2 & 63 & 38.9 & 68 & 34.0 \\
\hline Average 25-32 & 19 & 50.0 & 86 & 53.1 & 105 & 52.5 \\
\hline High 33-40 & 14 & 36.8 & 13 & 8.0 & 27 & 13.5 \\
\hline Total & 38 & 100.00 & 162 & 100.0 & 200 & 100.00 \\
\hline
\end{tabular}

Chi-Square $=24.984 \mathrm{df}=2 \mathrm{p} \leq 0.05$

Table 2. Distribution of mothers participating in the study according to residence area

\begin{tabular}{lcccccc}
\hline Residence area & \multicolumn{2}{c}{ Working } & \multicolumn{2}{c}{ Housewives } & \multicolumn{2}{c}{ Total } \\
\cline { 2 - 7 } & No. & $\mathbf{( \% )}$ & No. & $\mathbf{( \% )}$ & No. & $\mathbf{( \% )}$ \\
\hline Rural & 13 & 34.2 & 87 & 53.7 & 100 & 50.0 \\
Urban & 25 & 65.8 & 75 & 46.3 & 100 & 50.0 \\
Total & 38 & 100.0 & 162 & 100.0 & 200 & 100.0 \\
\hline Chi-Square $=4.678 \mathrm{df}=1$ & $\mathrm{p} \leq 0.05$ & & & & &
\end{tabular}

Chi-Square $=4.678 \mathrm{df}=1 \quad \mathrm{p} \leq 0.05$

of the working and housewives mothers were from urban area, respectively. Whereas, 34.2\% and $53.7 \%$ were from rural for working and housewives mothers, respectively. It is evident from the results that there were significant differences in working and housewife mothers according to residence area.

\section{Educational level of mother}

Table 3 describs the distribution of participants according to educational level of mothers in relation to the working and housewives mothers. These results explain that the highest percentage of mothers $(65.8 \%)$ had Bachelor's degree in the working mothers. While, the highest percentage of housewives mothers (46.9\%) had secondary school degree. The majority of working mothers were educated. On the other hand, the lowest percentage of the working mothers had (M.Sc./ Ph.D.) degree (18.4\%). The results specified that there were statistically significant differences in the working and housewives mothers according to educational level. Berihu et al. (2013) showed that mother's knowledge on nutritional requirement of infant and young child feeding in Mekelle, Ethiopia was found to be 180 (33.3\%) on primary education, $160(30.1 \%)$ were on the secondary education, $84(15.5 \%)$ were with no education, $78(14.4 \%)$ were with college diploma and the rest $36(6.7 \%)$ were those who can read and write.

\section{Marital status}

Distribution of respondent according to marital status are given in Table 4 . The results revealed that the majority of working and housewives mothers (92.1 and 97.5\%) were married. The results specified that there were statistically insignificant differences in the working and housewives mothers. 
Table 3. Distribution of mothers participating in the study according to educational level of mother

\begin{tabular}{lcccccc}
\hline Educational level of mother & \multicolumn{2}{c}{ Working } & \multicolumn{2}{c}{ Housewives } & \multicolumn{2}{c}{ Total } \\
\cline { 2 - 7 } & No. & $(\%)$ & No. & $(\%)$ & No. & $(\%)$ \\
\hline Illiterate & 1 & 2.6 & 9 & 5.6 & 10 & 5.0 \\
Read and write & 0 & 0.0 & 10 & 6.2 & 10 & 5.0 \\
Primary school & 0 & 0.0 & 17 & 10.5 & 17 & 8.5 \\
Secondary school & 5 & 13.2 & 76 & 46.9 & 81 & 40.5 \\
Bachelor's degree & 25 & 65.8 & 43 & 26.5 & 68 & 34.0 \\
(M.Sc./ Ph.D.) degree & 7 & 18.4 & 7 & 4.3 & 14 & 7.0 \\
Total & 38 & 100.0 & 162 & 100.0 & 200 & 100.0 \\
\hline
\end{tabular}

Chi-Square $=38.205 \mathrm{df}=5 \mathrm{p} \leq 0.05$

Table 4. Distribution of mothers participating in the study according to marital status

\begin{tabular}{lcccccc}
\hline Marital status & \multicolumn{2}{c}{ Working } & \multicolumn{2}{c}{ Housewives } & \multicolumn{2}{c}{ Total } \\
\cline { 2 - 7 } & No. & $\mathbf{( \% )}$ & No. & $\mathbf{( \% )}$ & No. & (\%) \\
\hline Married & 35 & 92.1 & 158 & 97.5 & 193 & 96.5 \\
Divorced & 1 & 2.6 & 2 & 1.25 & 3 & 1.5 \\
Widowed & 2 & 5.3 & 2 & 1.25 & 4 & 2.0 \\
Total & 38 & 100.0 & 162 & 100.0 & 200 & 100.0 \\
\hline
\end{tabular}

Chi-Square $=2.992 \mathrm{df}=2 \quad \mathrm{p} \leq 0.05$

\section{Gender of child}

Table 5 describs distribution of child gender. The results indicated that $63.2 \%$ were male and $36.8 \%$ were female for working mothers. Whereas, $46.9 \%$ were male and $53.1 \%$ were female for housewives.

\section{Child 's age per day}

Table 6 describs the distribution of participants according to child 's age per day. It is obvious that more than fifty percent of working mothers $(57.9 \%)$ had children their age ranged between 576 to 850 days, while, who aged 25 to 300 and 301 to 575 days were $21.1 \%$. Whereas, the highest proportion of housewives $(37.7 \%)$ had children their age was 25 to 300 , while, who aged 301to 575 days was $29.0 \%$ and those aged 576 to 850 days was $33.3 \%$. It is evident from the results that there were significant differences in working and housewives mothers according to child 's age per day.

\section{Chest circumference/head circumference of child}

Distribution per cent of participants according to chest circumference/head circumference of child is present in Table 7. It is obvious that the percentage of good nutrition children was 97.5 and $89.5 \%$ of housewives and working mothers, respectively. While, the percentage of nutritional deficiency children was less in housewives than working mothers and it reached $2.5 \%$ and in working mothers valued $10.5 \%$. This result may be due to working mothers are busy some time in their work every day. It is obvious from the present results that there were significant differences in working and housewife mothers according to chest circumference/head circumference of child. 
Table 5. Distribution of mothers participating in the study according to gender of child

\begin{tabular}{lcccccc}
\hline Gender of child & \multicolumn{2}{c}{ Working } & \multicolumn{2}{c}{ Housewives } & \multicolumn{2}{c}{ Total } \\
\cline { 2 - 7 } & No. & $\mathbf{( \% )}$ & No. & $\mathbf{( \% )}$ & No. & $\mathbf{( \% )}$ \\
\hline Male & 24 & 63.2 & 76 & 46.9 & 100 & 50.0 \\
Female & 14 & 36.8 & 86 & 53.1 & 100 & 50.0 \\
Total & 38 & 100.0 & 162 & 100.0 & 200 & 100.0 \\
\hline
\end{tabular}

Chi-Square $=3.249 \mathrm{df}=1 \quad \mathrm{p} \leq 0.05$

Table 6. Distribution of mothers participating in the study according to child's age per day

\begin{tabular}{lcccccc}
\hline Child 's age per day & \multicolumn{2}{c}{ Working } & \multicolumn{2}{c}{ Housewives } & \multicolumn{2}{c}{ Total } \\
\cline { 2 - 7 } & No. & $\mathbf{( \% )}$ & No. & $\mathbf{( \% )}$ & No. & $\mathbf{( \% )}$ \\
\hline Low 25-300 & 8 & 21.1 & 61 & 37.7 & 69 & 34.5 \\
Average 301-575 & 8 & 21.1 & 47 & 29.0 & 55 & 27.5 \\
High 576-850 & 22 & 57.9 & 54 & 33.3 & 76 & 38.0 \\
Total & 38 & 100.0 & 162 & 100.0 & 200 & 100.0 \\
\hline
\end{tabular}

Chi-Square $=8.055 \mathrm{df}=2 \quad \mathrm{p} \leq 0.05$

Table 7. Distribution of mothers participating in the study according to chest circumference / head circumference

\begin{tabular}{lcccccc}
\hline Chest circumference/head circumference & \multicolumn{2}{c}{ Working } & \multicolumn{2}{c}{ Housewives } & \multicolumn{2}{c}{ Total } \\
\cline { 2 - 7 } & No. & $\mathbf{( \% )}$ & No. & $\mathbf{( \% )}$ & No. & $\mathbf{( \% )}$ \\
\hline Nutritional deficiency & 4 & 10.5 & 4 & 2.5 & 8 & 4.0 \\
Good nutrition & 34 & 89.5 & 158 & 97.5 & 192 & 96.0 \\
Total & 38 & 100.0 & 162 & 100.0 & 200 & 100.0 \\
\hline
\end{tabular}

Chi-Square $=5.204 \mathrm{df}=1 \quad \mathrm{p} \leq 0.05$

\section{Source of nutritional knowledge of mothers}

Fig. 1 illustrats the sources of nutritional knowledge of the mothers about breast and artificial feeding. The results declared that the working mothers get nutritional knowledge $(63.2 \%)$ from visiting doctor, $57.9 \%$ from experience from her mother and grandmother, $44.7 \%$ from different stages of education, $36.8 \%$ from the media, $33 \%$ from other, $23.7 \%$ from health unit in country or center, $21.1 \%$ from friends, $19 \%$ from internet like facebook, $18.4 \%$ from books and magazines, $5 \%$ from relatives. While, housewives get nutritional knowledge $91.4 \%$ from other, $80.9 \%$ from experience from her mother and grandmother, $46.3 \%$ from visiting doctor, $26.5 \%$ from internet like Facebook, $25.9 \%$ from relatives, $17.9 \%$ from health unit in country or center, $15.4 \%$ from friends, $12.3 \%$ from the media, $10.5 \%$ from different stages of education, $1.2 \%$ from books and magazines. 


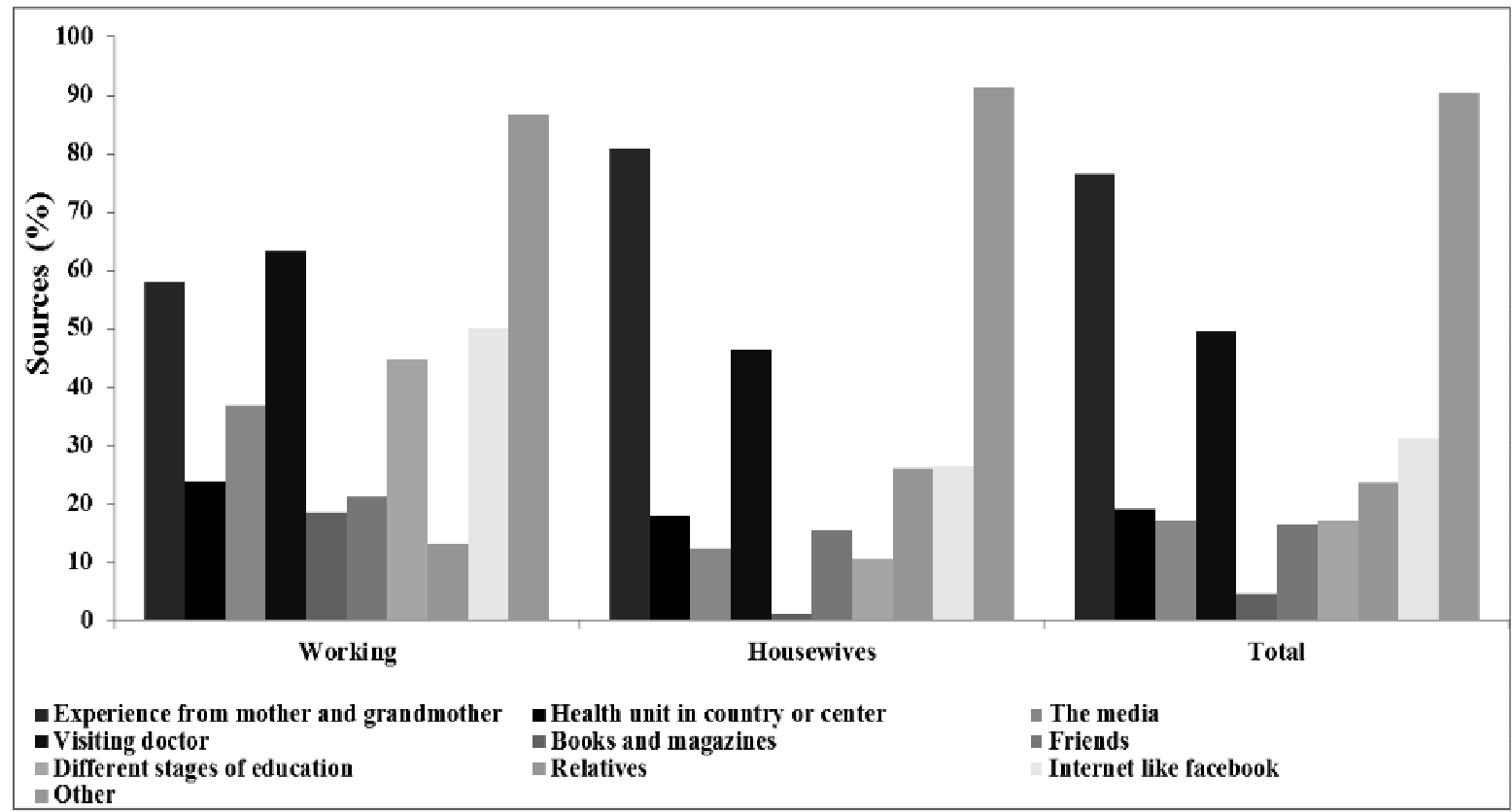

Fig. 1. Distribution of mothers participating in the study according to source of nutritional knowledge of mothers

\section{General Knowledge about Breast Feeding}

Table 8 shows the distribution of participants according to their general knowledge about breast feeding. The results defined that the majority of working and housewives mothers (81.6 and $79.0 \%$ ), respectively were not aware about "That children must be given natural breast feeding for 6 months without supplementary food" as shown in item 1. In the same Table the highest percentage of working and housewives mothers (100 and 95.7\%), respectively were aware about" Breast feeding is better for the baby than for artificial feeding" as shown in item 2. On the other hand, $92.1 \%$ of working mothers were aware than housewives $(89.5 \%)$, about "Breast feeding is recommended during the first hours of childbirth as" shown in item 3.The results defined that 65.8 and $47.5 \%$ of working and housewives mothers, respectively, were aware about" Breastfeeding is useful in returning the uterus to its normal state" as shown in item 4. The same Table evidenced mother's awareness percentage about "Natural breast feeding protects the mother from breast and ovarian cancer" as shown in item (5) It was $71.1 \%$ in working mothers and it was higher than housewives $(48.8 \%)$. Also results indicated that $92.1 \%$ of working mothers know that breast feeding should be continued during the child's illness, while, $76.5 \%$ from housewives know that as shown in item (6). In the same Table the highest percentage of working and housewives mothers (63.2 and 49.4\%), respectively, were aware about "Breastfeeding reduce from infecting children allergic" as shown in item (7). The results in item (8) defined that $64.4 \%$ of working mothers were aware about "It is best to continue breastfeeding for two years". On the other hand, $51.2 \%$ of housewives aware about that. Also indicated that $52.6 \%$ of working mothers knew that breast feeding helps to lose weight gained during pregnancy, while, $50.0 \%$ from housewives know that as shown in item (9). The results cleared that $42.6 \%$ of housewives were aware about "Avoid breast feeding during congestion of breast", as declared in item (10), while, working mothers was $39.5 \%$. As well as the $54.9 \%$ of housewives were aware about "We should not give the baby breast feeding during the fever of mothers", as declared in item (11), and it reached $52.6 \%$ of working mothers. Table 8 clear up the highest percentage of working mothers and housewives (73.7 and $61.7 \%$ ), respectively were aware about "Breast feeding contributes to improvement the 
Zagazig J. Agric. Res., Vol. 46 No. (6B) 2019

Table 8. Distribution of respondents mothers according to their knowledge about breast feeding

\begin{tabular}{|c|c|c|c|c|c|c|c|c|c|}
\hline \multirow[t]{2}{*}{ No. } & \multirow[t]{2}{*}{ Item } & \multirow[t]{2}{*}{ Response } & \multicolumn{2}{|c|}{ Working } & \multicolumn{2}{|c|}{ Housewives } & \multicolumn{2}{|c|}{ Total } & \multirow{2}{*}{$\begin{array}{l}\text { Chi- } \\
\text { Square }\end{array}$} \\
\hline & & & No. & $(\%)$ & No. & $(\%)$ & No. & $(\%)$ & \\
\hline \multirow{3}{*}{1} & \multirow{4}{*}{$\begin{array}{l}\text { The children must be given natural } \\
\text { breast feeding for } 6 \text { months without } \\
\text { supplementary food }\end{array}$} & I know & 1 & 2.6 & 10 & 6.2 & 11 & 5.5 & \\
\hline & & To some extent & 6 & 15.8 & 24 & 14.8 & 30 & 15.0 & 0.747 \\
\hline & & I don't know & 31 & 81.6 & 128 & 79.0 & 159 & 79.5 & \\
\hline \multirow{3}{*}{2} & & I know & 38 & 100.0 & 155 & 95.7 & 193 & 96.5 & \\
\hline & \multirow{2}{*}{$\begin{array}{l}\text { Breast feeding is better for baby than } \\
\text { the artificial feeding }\end{array}$} & To some extent & 0 & 0.0 & 5 & 3.1 & 5 & 2.5 & 1.702 \\
\hline & & I don't know & 0 & 0.0 & 2 & 1.2 & 2 & 1.0 & \\
\hline \multirow{3}{*}{3} & \multirow{3}{*}{$\begin{array}{l}\text { Breast feeding is recommended } \\
\text { during the first hours of childbirth }\end{array}$} & I know & 35 & 92.1 & 145 & 89.5 & 180 & 90.0 & \\
\hline & & To some extent & 0 & 0.0 & 10 & 6.2 & 10 & 5.0 & 3.155 \\
\hline & & I don't know & 3 & 7.9 & 7 & 4.3 & 10 & 5.0 & \\
\hline \multirow{3}{*}{4} & \multirow{3}{*}{$\begin{array}{l}\text { Breast feeding is useful in returning } \\
\text { the uterus to its normal state }\end{array}$} & I know & 25 & 65.8 & 77 & 47.5 & 102 & 51.00 & \\
\hline & & To some extent & 7 & 18.4 & 27 & 16.7 & 34 & 17.0 & $5.920^{*}$ \\
\hline & & I don't know & 6 & 15.8 & 58 & 35.8 & 64 & 32.0 & \\
\hline \multirow{3}{*}{5} & \multirow{3}{*}{$\begin{array}{l}\text { Natural breast feeding protects the } \\
\text { mother from breast and ovarian } \\
\text { cancer }\end{array}$} & I know & 27 & 71.1 & 79 & 48.8 & 106 & 53.0 & \\
\hline & & To some extent & 7 & 10.5 & 28 & 17.3 & 32 & 16.0 & $6.158^{*}$ \\
\hline & & I don't know & 4 & 18.4 & 55 & 34.0 & 62 & 31.0 & \\
\hline \multirow{3}{*}{6} & \multirow{3}{*}{$\begin{array}{l}\text { Breast feeding should be continued } \\
\text { during the child's illness }\end{array}$} & I know & 35 & 92.1 & 124 & 76.5 & 159 & 79,5 & \\
\hline & & To some extent & 3 & 7.9 & 27 & 16.7 & 30 & 15.0 & 5.097 \\
\hline & & I don't know & 0 & 0.00 & 11 & 6.8 & 11 & 51.1 & \\
\hline \multirow{3}{*}{7} & \multirow{3}{*}{$\begin{array}{l}\text { Breast feeding reduce from infecting } \\
\text { children allergic }\end{array}$} & I know & 24 & 63.2 & 80.0 & 49.4 & 104 & 52.0 & \\
\hline & & To some extent & 11 & 28.9 & 40 & 24.7 & 51 & 25.0 & $5.790^{*}$ \\
\hline & & I don't know & 3 & 7.9 & 42 & 25.9 & 45 & 22.5 & \\
\hline \multirow{4}{*}{8} & \multirow{3}{*}{$\begin{array}{l}\text { It is best to continue breast feeding } \\
\text { for two years }\end{array}$} & I know & 26 & 64.4 & 85 & 51.2 & 10.5 & 54.5 & \\
\hline & & To some extent & 7 & 18.4 & 55 & 34.0 & 62 & 31.0 & 4.121 \\
\hline & & I don't know & 5 & 13.2 & 24 & 14.8 & 29 & 14.5 & \\
\hline & & I know & 20.0 & 52.6 & 81 & 50.0 & 101 & 50.5 & \\
\hline \multirow[t]{3}{*}{9} & $\begin{array}{l}\text { Breast feeding helps to lose weight } \\
\text { gained during pregnancy }\end{array}$ & To some extent & 8 & 21.1 & 33 & 20.4 & 41 & 20.0 & 0.166 \\
\hline & & I don't know & 10 & 26.3 & 48 & 29.6 & 58 & 29.0 & \\
\hline & & I know & 15 & 39.5 & 69 & 42.6 & 84 & 42.0 & \\
\hline \multirow[t]{3}{*}{10} & $\begin{array}{l}\text { Avoid breast feeding during congestion } \\
\text { of breast }\end{array}$ & To some extent & 8 & 21.1 & 34 & 21.0 & 42 & 21.0 & 0.149 \\
\hline & & I don't know & 15 & 35.6 & 59 & 36.4 & 74 & 37.0 & \\
\hline & Total & & 78 & 100.0 & 162 & 100.0 & 200 & 100.0 & \\
\hline
\end{tabular}


Table 8. Cont.

\begin{tabular}{|c|c|c|c|c|c|c|c|c|c|}
\hline \multirow[t]{2}{*}{$\overline{\text { No. }}$} & \multirow[t]{2}{*}{ Item } & \multirow[t]{2}{*}{ Response } & \multicolumn{2}{|c|}{ Working } & \multicolumn{2}{|c|}{ House wife } & \multicolumn{2}{|c|}{ Total } & \multirow{2}{*}{$\begin{array}{l}\text { Chi- } \\
\text { Square }\end{array}$} \\
\hline & & & No. & $(\%)$ & No. & $(\%)$ & No. & $(\%)$ & \\
\hline \multirow{3}{*}{1} & & I know & 20 & 52.6 & 89 & 54.9 & 109 & 54.5 & \multirow{3}{*}{2.097} \\
\hline & & To sc & 8 & 21.1 & 20 & 12.3 & 28 & 14.0 & \\
\hline & & $\mathrm{I} d$ & 10 & 26.3 & 53 & 32.7 & 63 & 31.5 & \\
\hline \multirow{4}{*}{12} & & I knov & 28 & 73.7 & 100 & 61.7 & 128 & 64.0 & \multirow{3}{*}{2.090} \\
\hline & Cast & To some extent & 4 & 10.5 & 20 & 12.3 & 24 & 12.0 & \\
\hline & & I don’t know & 6 & 15.8 & 42 & 25.9 & 48 & 24.0 & \\
\hline & & $\mathrm{Ik}$ & 33 & 86.8 & 145 & 89.5 & 178 & 89.0 & \multirow{3}{*}{2.395} \\
\hline \multirow[t]{3}{*}{13} & Breast feeding helps in saving money & To some & 5 & 13.2 & 12 & 7.4 & 17 & 8.5 & \\
\hline & and time & I don’t know & 0 & 0.0 & 5 & & 5 & 2.5 & \\
\hline & & I kn & 38 & 100.0 & 157 & 96.9 & 195 & 97.5 & \multirow{3}{*}{1.203} \\
\hline \multirow[t]{3}{*}{14} & Breast & To some & 0 & 0.0 & 3 & 1.9 & 3 & 1.5 & \\
\hline & & I don & 0 & 0.0 & 2 & & 2 & 1.0 & \\
\hline & Breast feedi & $\mathrm{Ik}$ & 33 & 86.8 & 140 & 86.4 & 173 & 6.5 & \multirow{3}{*}{1.051} \\
\hline \multirow[t]{3}{*}{15} & ve and & To son & 5 & 13.2 & 18 & 11.1 & 23 & 11.5 & \\
\hline & behavioral sk & I don & 0 & 0.0 & 4 & 2.5 & 4 & 2.0 & \\
\hline & Breast feeding helps to support the & $\mathrm{I} \mathrm{k}$ & 37 & 97.4 & 148 & 91.4 & 185 & 92.5 & \multirow{3}{*}{1.711} \\
\hline \multirow[t]{3}{*}{16} & ne system and improvement the & To some & 1 & 2.6 & 11 & 6.8 & 12 & 6.0 & \\
\hline & s the the child & I don't & 0 & 0 & 3 & & 3 & 1. & \\
\hline & um is contained the antibodies & I know & 37 & 97.4 & 143 & 88.3 & 180 & 90.0 & \\
\hline \multirow[t]{2}{*}{17} & against & To some & 1 & 2. & 10 & 6. & 11 & 5.5 & 3.096 \\
\hline & & I dor & 0 & 0 & 9 & 5. & 9 & 4 & \\
\hline & & & 33 & 86.8 & 132 & 81.5 & 165 & 82.5 & \\
\hline 18 & & To som & 1 & 26 & 21 & 13.0 & 22 & 11.0 & 4.264 \\
\hline & & & 4 & & 9 & & 13 & & \\
\hline & & I 1 & 35 & 92.1 & 131 & 80.9 & 166 & 83.0 & \\
\hline 19 & & To sc & $3+2>$ & 7.9 & 2 & 3 & 23 & 11.5 & 3.579 \\
\hline & & $\mathrm{Id}$ & 0 & 0.0 & 11 & 7 & 11 & 5.5 & \\
\hline & & & 36 & 94.7 & 144 & 88.9 & 180 & 90.0 & \\
\hline 0 & & To son & 2 & 5. & 15 & 9 & 17 & 8.5 & 1.399 \\
\hline & & I don' & 0 & 0.0 & 3 & 1 & 3 & 1.5 & \\
\hline & tional & I know & 38 & 100.0 & 148 & 91.4 & 186 & 93.0 & \\
\hline 1 & & To sc & 0 & 0.0 & 1 & 7. & 12 & 6 & 3.531 \\
\hline & & I do & 0 & & 2 & & 2 & 1.0 & \\
\hline & ep & & 25 & 65.8 & 71 & 43.8 & 96 & 48.0 & \\
\hline 22 & not & To som & 7 & & 1 & & 52 & 0 & $6.011^{*}$ \\
\hline & & I do & 6 & & & & 52 & 26.0 & \\
\hline & & $\mathrm{I} \mathrm{kn}$ & 27 & 1 & 91 & 56.2 & 118 & 59.0 & \\
\hline 23 & & To some & 6 & & $3+3$ & & 42 & 21.0 & 860 \\
\hline & & I do & 5 & & 35 & & 40 & & \\
\hline & $\mathbf{v}$ & I 1 & 25 & 65 & 119 & 73.5 & 144 & 72.0 & \\
\hline 24 & 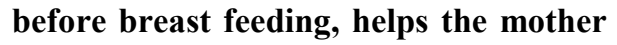 & To sor & 8 & & 24 & & 32 & 16.0 & .052 \\
\hline & & & 5 & & & & 24 & & \\
\hline & Eating some foods such as leafy & I kno & 31 & 81.6 & 139 & 85.8 & 170 & 85.0 & \\
\hline 25 & alva, drink th & o som & 4 & 10.5 & 11 & 6.8 & 15 & 1.5 & 04 \\
\hline & $\begin{array}{l}\text { llk helps the mother to produce } \\
\text { iilk }\end{array}$ & I don't know & 3 & 7.9 & 12 & 7.4 & 15 & 7.5 & \\
\hline & Total & & 38 & 100.0 & 162 & 100.0 & 200 & 100.0 & \\
\hline
\end{tabular}


health of mothers' as shown in item (12). In addition, Table 8 shown mothers awareness percentage about "Breast feeding helps in saving money and time" as show in item (13) was $89.5 \%$ in housewives and it was higher than working mothers $(86.8 \%)$. While, $100 \%$ of working mothers were aware in item (14) about "Breast feeding is good for her child health", but $96.9 \%$ of housewives knew that. In item (15) the percentage of working mothers and housewives (86.8 and $86.4 \%$ ), respectively, was aware that "breast feeding is useful in raising the level of intelligence and cognitive and behavioral skills". Also, indicated the percentage of mothers awareness in item (16) about "Breast feeding helps to support the immune system and improvement the digestion process to the child" was higher in working mothers $(97.4 \%)$ than housewives $(91.4 \%)$. Furthermore, $97.4 \%$ of working mothers were conscious about "Colostrum is contained the antibodies needed to protect the child against diseases", as shown in item (17) and $88.3 \%$ of housewives conscious about that.

Over, $86.8 \%$ of working mothers were aware about "Human milk contains all food elements sufficient for the baby", as shown in item (18) and this result more than housewives $(81.5 \%)$. As well as the Table mention the percentage of mothers awareness in item (19) about "Breast feeding increases the secretion of breast milk" was higher in working mothers $(92.1 \%)$ than housewives $(80.9 \%)$.

Whereas, (94.7\%) of working mothers are familiar with item (20) on "Breast milk achieves a sense of food safety for the infant", but $(88.9 \%)$ of housewives know this. The results obtained that $(100 \%)$ of working mothers were aware about "Human milk strengthens the emotional and psychological relationship between the mother and child", as declared in item (21) and this result more than housewives (91.4\%(. On other hand, $65.8 \%$ of working mothers were conscious about "Lack of sleep and stress affect the secretion of mother milk", as defined in item (22), and $43.8 \%$ of housewives know this. Otherwise, Table 8 indicated that $71.1 \%$ of working mothers know to some extent that Intake some drugs affect the secretion of breast milk and then the child, while $56.2 \%$ of housewives knew that as shown in item (23).
In addition, the same Table manifest mothers awareness percentage about "Drinking too much water, especially before breast feeding helps the mother to produce more milk " as shown in item (24) it was $73.5 \%$ in housewives and it was higher than working mothers $65.8 \%$. Moreover, $85.8 \%$ of housewives were aware about "Eating some foods such as leafy vegetables, halwa, drink the fenugreek and milk helps the mother to produce more milk ", as declared in item (25) and this result more than working mothers $81.6 \%$. It is obvious from the present study that there were statistically significant differences in some knowledge items number (4, 5, 7 and 22) regarding general knowledge about breast feeding among all studies subjects (working and housewives mothers).

\section{General Knowledge about Artificial Feeding}

Table 9 shows distribution of participants according to their general knowledge about artificial feeding. The results defined that the highest percentage 65.8 and $65.4 \%$ of working and housewife mothers, respectively, don't know that artificial feeding is give industrial milk or animals dairy to babies as a substitute for mother milk when the mother has an illness that could be passed on to the baby through breast milk or presence a condition impede breast feeding the baby naturally as shown in item (1). Mothers response in item (2) defined that $73.7 \%$ of working mothers and $35.8 \%$ of housewives know artificial feeding helps to know the amount of milk the child is intake. Whereas, $(52.6 \%)$ of working mothers are familiar with item (3) on "The time, which is spend the child in formula feeding less than that in breastfeeding", but (42.6\%) of housewives know this. The results declared that $78.9 \%$ of working mothers were aware about "The absorption of minerals from breast milk is better than that found in artificial milk", as declared in item (4) than this result more than housewives (66.7\%). Mothers reply as shown in item (5) showed that 78.9 and $73.5 \%$ of working mothers and housewives, respectively, were aware about "Artificial feeding takes effort during the preparation and cleaning process". On other hand, $65.8 \%$ of working mothers were conscious about "Artificial feeding leads to increased intestinal infections and diarrhea ", as defined in item (6), and it was $56.8 \%$ of housewives. The 
Table 9. Distribution of respondents mothers according to their knowledge about artificial feeding

\begin{tabular}{|c|c|c|c|c|c|c|c|c|c|}
\hline \multirow[t]{2}{*}{ No. } & \multirow[t]{2}{*}{ Item } & \multirow[t]{2}{*}{ Response } & \multicolumn{4}{|c|}{ Working Housewife } & \multicolumn{2}{|c|}{ Total } & \multirow{2}{*}{$\begin{array}{l}\text { Chi- } \\
\text { Square }\end{array}$} \\
\hline & & & No. & $(\%)$ & No. & $(\%)$ & No. & $(\%)$ & \\
\hline \multirow{3}{*}{, } & Artificial feeding is give industrial milk or & I know & 25 & 23.7 & 37 & 22.8 & 462 & 23.0 & \\
\hline & $\begin{array}{l}\text { animais dairy to babies as a substitute for } \\
\text { mother milk when the mother has an illness }\end{array}$ & To some extent & 4 & 10.5 & 19 & 11.7 & 23 & 11.5 & 0.049 \\
\hline & $\begin{array}{l}\text { breast milk or presence a conditions impede } \\
\text { breastfeeding the baby naturally }\end{array}$ & I don't know & 9 & 65.8 & 106 & 65.4 & 131 & 65.5 & \\
\hline \multirow{3}{*}{2} & \multirow{3}{*}{$\begin{array}{l}\text { Artificial feeding helps to know the amount of } \\
\text { milk the child is intake }\end{array}$} & I know & 28 & 73.7 & 81 & 35.8 & 1095 & 54.5 & \\
\hline & & To some extent & 3 & 7.9 & 23 & 14.2 & 26 & 13.0 & $6.970^{*}$ \\
\hline & & I don't know & 7 & 18.4 & 58 & 50.0 & 65 & 32.5 & \\
\hline \multirow{3}{*}{3} & \multirow{3}{*}{$\begin{array}{l}\text { The time, which is spend the child in artificial } \\
\text { feeding less than that in breast feeding }\end{array}$} & I know & 20 & 52.6 & 69 & 42.6 & 89 & 44.5 & \\
\hline & & To some extent & 6 & 15.8 & 23 & 14.2 & 29 & 14.5 & 1.766 \\
\hline & & I don't know & 12 & 31.6 & 70 & 43.2 & 82 & 41.0 & \\
\hline \multirow{3}{*}{4} & \multirow{3}{*}{$\begin{array}{l}\text { The absorption of minerals from breast milk } \\
\text { is better than that found in artificial milk }\end{array}$} & I know & 30 & 78.9 & 108 & 66.7 & 138 & 69.0 & \\
\hline & & To some extent & 4 & 10.5 & 11 & 6.8 & 15 & 7.5 & 4.606 \\
\hline & & I don't know & 4 & 10.5 & 43 & 26.5 & 472 & 23.5 & \\
\hline \multirow{3}{*}{5} & \multirow{3}{*}{$\begin{array}{l}\text { Artificial feeding takes effort during the } \\
\text { preparation and cleaning process }\end{array}$} & I know & 30 & 78.9 & 119 & 73.5 & $149^{\circ}$ & 74.5 & \\
\hline & & To some extent & 4 & 10.5 & 12 & 7.4 & 16 & 8.0 & 1.803 \\
\hline & & I don't know & 4 & 10.5 & 31 & 19.1 & 35 & 17.5 & \\
\hline \multirow{3}{*}{6} & \multirow{3}{*}{$\begin{array}{l}\text { Artificial feeding leads to increased intestinal } \\
\text { infections and diarrhea }\end{array}$} & I know & 25 & 65.8 & 92 & 56.8 & 117 & 58.5 & \\
\hline & & To some extent & 6 & 15.8 & 27 & 16.7 & 33 & 16.5 & 1.253 \\
\hline & & I don't know & 7 & 18.4 & 43 & 26.5 & 50 & 25.0 & \\
\hline \multirow{3}{*}{7} & \multirow{3}{*}{$\begin{array}{l}\text { Artificial feeding affects the child's immunity } \\
\text { negatively }\end{array}$} & I know & 26 & 68.4 & 91 & 56.2 & 117 & 58.5 & \\
\hline & & To some extent & 6 & 15.8 & 26 & 16.0 & 32 & 16.0 & 2.525 \\
\hline & & I don't know & 6 & 15.8 & 45 & 27.5 & 51 & 25.0 & \\
\hline \multirow{3}{*}{8} & \multirow{3}{*}{ Artificial feeding leads to obesity in children } & I know & 24 & 63.2 & 79 & 48.8 & 103 & 51.5 & \\
\hline & & To some extent & 7 & 18.4 & 28 & 17.3 & 35 & 17.5 & 3.655 \\
\hline & & I don't know & 7 & 18.4 & 55 & 34.0 & 62 & 31.0 & \\
\hline \multirow{3}{*}{9} & \multirow{3}{*}{$\begin{array}{l}\text { Cow's milk contains a protein that causes } \\
\text { allergies to children }\end{array}$} & I know & 17 & 44.7 & 67 & 41.4 & 84 & 42.0 & \\
\hline & & To some extent & 8 & 21.1 & 25 & 15.4 & 33 & 16.5 & 1.274 \\
\hline & & I don't know & 13 & 34.2 & 70 & 43.2 & 83 & 41.5 & \\
\hline \multirow{3}{*}{10} & \multirow{3}{*}{ Artificial milk does not contain antibodies } & I know & 18 & 47.4 & 53 & 32.7 & 71 & 35.5 & \\
\hline & & To some extent & 9 & 23.7 & 39 & 24.1 & 48 & 24.0 & 3.409 \\
\hline & & I don't know & 11 & 28.9 & 70 & 43.2 & 81 & 40.5 & \\
\hline
\end{tabular}


Table 9. Cont.

\begin{tabular}{|c|c|c|c|c|c|c|c|c|c|}
\hline \multirow[t]{2}{*}{ No. } & \multirow[t]{2}{*}{ Item } & \multirow[t]{2}{*}{ Response } & \multicolumn{4}{|c|}{ Working House wife } & \multirow{2}{*}{\multicolumn{2}{|c|}{$\frac{\text { Total }}{\text { No. }(\%)}$}} & \multirow{2}{*}{$\begin{array}{l}\text { Chi- } \\
\text { Square }\end{array}$} \\
\hline & & & $\overline{\text { No. }}$ & $(\%)$ & No. & $(\%)$ & & & \\
\hline \multirow{3}{*}{11} & & I know & 29 & 76.3 & 108 & 66.7 & 137 & 68.5 & \\
\hline & $\begin{array}{l}\text { Artificial milk contamination is easily from } \\
\text { several sources }\end{array}$ & To some extent & 3 & 7.9 & 18 & 11.1 & 21 & 10.5 & 1.328 \\
\hline & & I don't know & 6 & 15.8 & 36 & 22.2 & 42 & 21.0 & \\
\hline \multirow{4}{*}{12} & & I know & 29 & 76.3 & 117 & 72.2 & 146 & 73.0 & \\
\hline & $\begin{array}{l}\text { The spoilage speed of the artificial milk } \\
\text { especially in the summer }\end{array}$ & To some extent & 3 & 7.9 & 16 & 9.9 & 19 & 9.9 & 0.276 \\
\hline & & I don't know & 6 & 15.8 & 29 & 17.9 & 36 & 17.5 & \\
\hline & & I know & 20 & 52.6 & 66 & 40.7 & 86 & 43.0 & \\
\hline \multirow[t]{2}{*}{13} & Artificial milk can be diluted too much, & To some extent & 7 & 18.4 & 34 & 21.0 & 41 & 20.5 & 1.844 \\
\hline & $\begin{array}{l}\text { leading to not get the infant his nutritional } \\
\text { needs }\end{array}$ & I don't know & 11 & 28.9 & 62 & 38.3 & 73 & 36.5 & \\
\hline \multirow{4}{*}{14} & & I know & 30 & 78.9 & 98 & 60.9 & 128 & 64.3 & \\
\hline & $\begin{array}{l}\text { Changing the type artificial milk in some } \\
\text { cases may be lead to diarrhea }\end{array}$ & To some extent & 2 & 5.3 & 17 & 10.6 & 19 & 9.5 & 4.387 \\
\hline & & I don't know & 6 & 15.8 & 46 & 28.6 & 52 & 26.1 & \\
\hline & & I know & 32 & 84.2 & 131 & 80.9 & 136 & 81.5 & \\
\hline \multirow[t]{3}{*}{15} & Artificial milk is expensive & To some extent & 1 & 2.6 & 5 & 3.1 & 6 & 3.0 & 0.230 \\
\hline & & I don't know & 5 & 13.2 & 26 & 16.0 & 31 & 15.5 & \\
\hline & & I know & 28 & 73.7 & 94 & 58.0 & 122 & 61.0 & \\
\hline \multirow[t]{2}{*}{16} & $\begin{array}{l}\text { Wide or narrow bottle nipples can be cause } \\
\text { some problems for the baby during feeding }\end{array}$ & To some extent & 4 & 10.5 & 23 & 14.2 & 27 & 13.5 & 3.279 \\
\hline & & I don't know & 6 & 15.8 & 45 & 27.8 & 51 & 25.5 & \\
\hline \multirow{4}{*}{17} & & I know & 14 & 36.8 & 63 & 38.9 & 77 & 83.5 & \\
\hline & $\begin{array}{l}\text { Bottle nipples affect the normal shape of the } \\
\text { child's jaw }\end{array}$ & To some extent & 12 & 31.6 & 25 & 15.4 & 37 & 18.5 & $5.794 *$ \\
\hline & & I don't know & 12 & 31.6 & 74 & 45.7 & 68 & 43.0 & \\
\hline & Total & & 38 & 100.0 & 162 & $\begin{array}{c}100 . \\
0\end{array}$ & 200 & $\begin{array}{c}100 . \\
0\end{array}$ & \\
\hline
\end{tabular}

*P $\leq 0.05$

results evidenced that $(68.4 \%)$ of working mothers were aware about "Artificial feeding affects the child's immunity negatively", as declared in item (7) and this results was more than housewives $(56.2 \%)$. As well as, the Table mention the percentage of mothers awareness in item (8) about "Artificial feeding leads to obesity in children" was higher in working mothers $(63.2 \%)$ than housewives $(48.8 \%)$. The results in item (9) revealed that (34.2 and $43.2 \%$ ) of working mothers and housewives, respectively, weren't aware about "Cow's milk contains a protein that causes allergies to children". The results that are given in item (10) of working mothers and housewives (47.4 and $32.7 \%$ ), respectively, were aware about "Artificial milk does not contain antibodies". While, the results in item (11) indicated that about $(76.3 \%)$ of working mothers and $(66.7 \%)$ of housewives know that artificial milk contamination is easily from several sources. Furthermore, $76.3 \%$ of working mothers were conscious about "The spoilage speed of the artificial milk especially in the summer", as 
shown in item (12) and $72.2 \%$ of housewives are conscious about that. This Table also obvious that the percentage of working mothers who knew that artificial milk can be diluted too much, leading to not get the infant his nutritional needs, was $52.6 \%$, while, $40.7 \%$ from housewives knew that as shown in item (13). Mothers reply as shown in item (14) showed that $(78.9$ and $60.9 \%)$ of working mothers and housewives, respectively, were aware about "Changing the type of artificial milk in some cases may be lead to diarrhea". Over, $84.2 \%$ of working mothers were aware about "Artificial milk is expensive", as shown in item (15) and this result more than housewives $80.9 \%$. On other hand, $(73.7 \%)$ of working mothers were conscious about " Wide or narrow bottle nipples can be cause some problems for the baby during feeding", as defined in item (16), and it was (58.0\%) of housewives. In addition, the same Table show mothers awareness percentage about "Bottle nipples affect the normal shape of the child's jaw " as show in item (17) was $38.9 \%$ in housewives and it was higher than working mothers $36.8 \%$. It is obvious from the present study that there were statistically significant differences in some knowledge items number (2 and 17) regarding general knowledge about breast feeding among all studies subjects (working and housewives mothers).

\section{Level of Knowledge About Breast and Artificial Feeding}

As shown in Table 10, the results illustrated that the highest percentage of working and housewife mothers (84.2 and 60.5\%) had low level of general knowledge about breast feeding. It is obvious from the present study that there were significant differences between subjects (working and housewife mothers) and levels of knowledge about breast feeding. Also, most of working and housewife mothers (76.3 and $62.3 \%$ ) had low level of general knowledge about artificial feeding (Table 11).

\section{Conclusion}

From the current study, it could be concluded that the most of working mothers and housewives (84.2 and $60.5 \%$ ) had low level of knowledge about breast and artificial feeding (working mothers and housewives, 76.3\% and $62.5 \%$ ) in Sharkia Governorate, Egypt during the period from March to May 2019.

Table 10. Distribution of participants according to level of knowledge about breast feeding

\begin{tabular}{lcccccc}
\hline Breast feeding & \multicolumn{2}{c}{ Working } & \multicolumn{2}{c}{ Housewives } & \multicolumn{2}{c}{ Total } \\
\cline { 2 - 7 } & No. & $\mathbf{( \% )}$ & No. & $\mathbf{( \% )}$ & No. & $(\%)$ \\
\hline Low(25-36) & 32 & 84.2 & 98 & 60.5 & 130 & 65.0 \\
Average (37-48) & 5 & 13.2 & 60 & 37.0 & 65 & 32.5 \\
High(23-37) & 1 & 2.6 & 4 & 2.5 & 5 & 2.5 \\
Total & 38 & 100.0 & 162 & 100.0 & 200 & 100.0 \\
\hline
\end{tabular}

Chi-Square $=8.067 \mathrm{DF}=2 \mathrm{P}=0.018$

Table 11. Distribution of participants according to level of knowledge about artificial feeding

\begin{tabular}{lcccccc}
\hline Artificial feeding & \multicolumn{2}{c}{ Working } & \multicolumn{2}{c}{ Housewives } & \multicolumn{2}{c}{ Total } \\
\cline { 2 - 7 } & No. & $\mathbf{( \% )}$ & No. & $\mathbf{( \% )}$ & No. & $(\%)$ \\
\hline Low 17-28 & 29 & 76.3 & 101 & 62.3 & 130 & 65.0 \\
Average 29-40 & 3 & 7.9 & 22 & 13.6 & 25 & 12.5 \\
High 41-52 & 6 & 15.8 & 39 & 24.1 & 45 & 22.5 \\
Total & 38 & 100.0 & 162 & 100.0 & 200 & 100.0 \\
\hline
\end{tabular}

Chi-Square $=2.659 \mathrm{DF}=2 \mathrm{P}=0.265$ 


\section{REFERENCES}

Berihu, A., G.G.B. Abera, H. Berhe and K. Kidanu (2013). Mother's knowledge on nutritional requirement of infant and young child feeding in Mekelle, Ethiopia, cross sectional study. Global. J. Med. Res. Interdisciplinary, 13 (6): 0975-5888.

Manikyamba, D., D.L. Vidya, A. Satyavani, P.A. Krishna and K.T. Deepthi (2015). Impact of nutritional education on the knowledge of mothers regarding infant and young child feeding practices. Scholars J. Appl. Med. Sci., 3 (3A): 1074-1078.

Mardhiah, D., I. Ekayanti and B. Setiawan (2019). The relationship between mother's nutritional knowledge towards fruits vegetables consumption and nutritional status of preschool children Kindergarten Salman, Jakarta. KnE Life Sciences/The $3^{\text {rd }}$ International Meeting of Public Health and the $1^{\text {st }}$ Young Scholar Symposium on Public Health, 47-52.

McLeod, E.R., K.J. Campbell and K.D. Hesketh (2011). Nutrition knowledge: A mediator between socioeconomic position and diet quality in Australian first-time mothers. J. Ame. Dietetic Assoc., 111: 696-704.

Nicklas, T.A. (1995). Dietary studies of children and young adults (1973-1988): The Bogalusa Heart Study. Ame. J. Med. Sci., 310: 101108.
Nicklas, T.A. and D. Hayes (2008). Position of the American Dietetic Association: nutrition guidance for healthy children ages 2 to 11 years. J. Ame. Dietetic Assoc., 108: 1038 1047.

Romanos-Nanclares, A., I. Zazpe, S. Santiago, L. Marín, A. Rico-Campà and N. MartínCalvo (2018). Influence of parental healthyeating attitudes and nutritional knowledge on nutritional adequacy and diet quality among preschoolers. The SENDO Project. Nutr., 10 (12): 1875-1889.

Variyam, J.N., J. Blaylock, B.H. Lin, K. Ralston and D. Smallwood (1999). Mother's nutrition knowledge and children's dietary intakes. Ame. Agric. Econ. Assoc., 81: 373-384.

Vereecken, C. and L. Maes (2010). Young children's dietary habits and associations with the mothers' nutritional knowledge and attitudes. Appetite, $54: 44$.

Yabanc, N., İ. Kısaç and S.Ş. Karakuş (2013). The effects of mother's nutritional knowledge on attitudes and behaviors of children about nutrition. Procedia-Social and Behavioral Sci., 116 : 4477 - 4481.

Zarnowiecki, D., N. Sinn, J. Petkov and J. Dollman (2012). Parental nutrition knowledge and attitudes as predictors of 5-6-year-old children's healthy food knowledge. Public Health Nutr., 15: 1284-1290. 


\section{دراسـة مسـتوى المعرفة الذذائية لاى الامهات بالرضاعة الطبيعية والصناعية في محافظة الثــرقيـة}

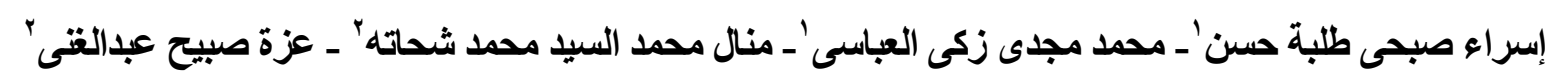

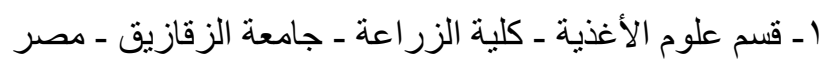

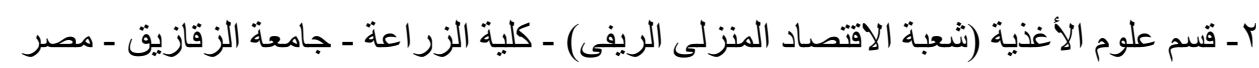

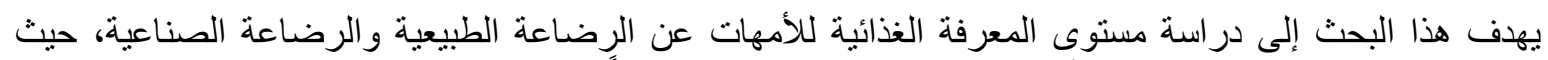

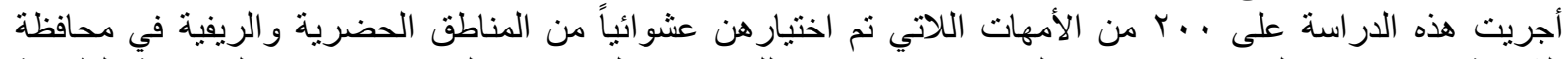

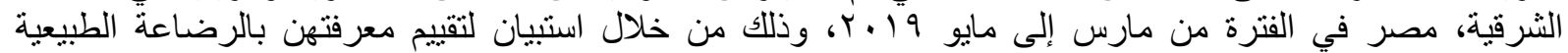

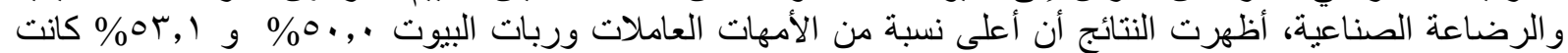

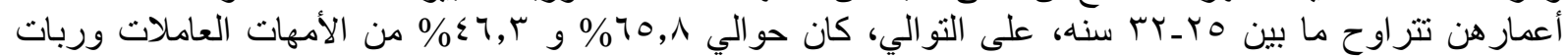

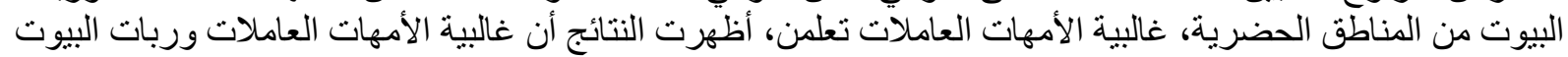

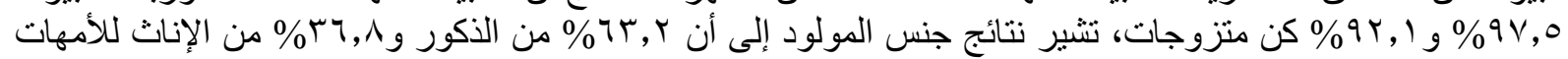

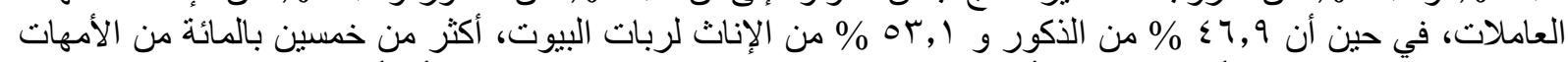

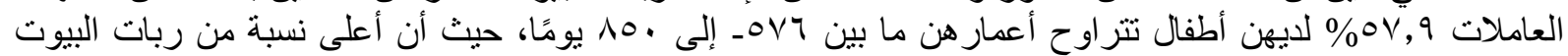

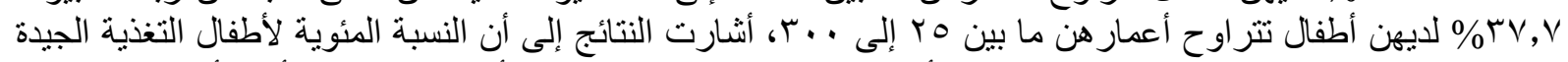

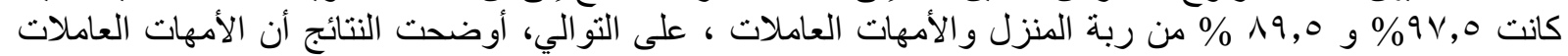

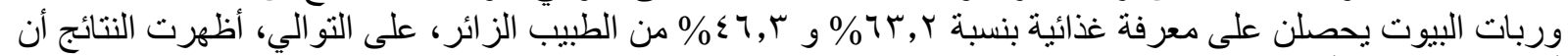

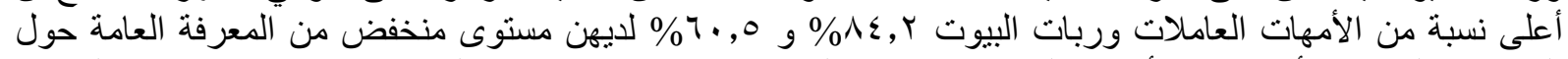

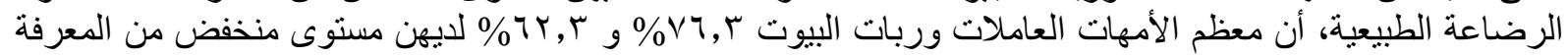

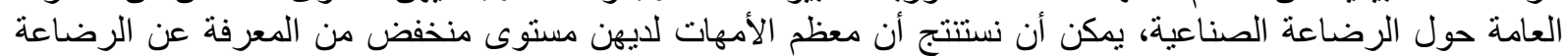

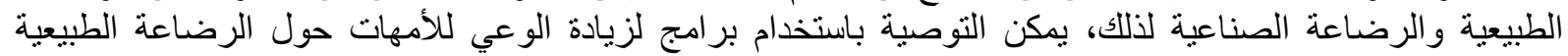
والرضاعة الصناعية.

أستاذ التغذية و علوم الأطعمة و عميد كلية التربية النوعية - جامعة الزقازيق.

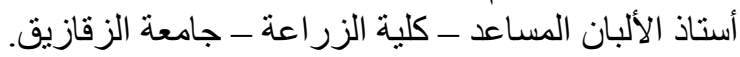

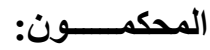

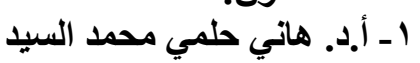

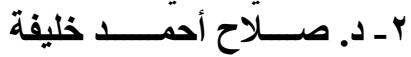

